\title{
Synthesis of tetrahydroselenophene derivatives by electrophilic cyclization of 1-butylseleno-4-alkynes
}

\author{
Rafaela Gai, Ricardo F. Schumacher and Gilson Zeni*
}

Laboratório de Síntese, Reatividade, Avaliação Farmacológica e Toxicológica de Organocalcogênios,

CCNE, UFSM, Santa Maria-Rio Grande do Sul, Brazil 97105-900

*gzeni@pq.cnpq.br

Keywords: selenophene, selenium, electrophilic cyclization

\section{INTRODUCTION}

Selenophene heterocycles and their derivatives have numerous uses in the fields of biochemistry, physical organic chemistry, material chemistry and organic synthesis. ${ }^{1}$ For example, selenophenes are widely studied agents with a diverse array of biological effects, these include antioxidant action, antinociceptive and antiinflammatory properties. ${ }^{2}$ A great number of these heterocycles have been synthesized and their chemistry has attracted a good deal of interest and activity from a variety of standpoints. ${ }^{3}$ However, the synthetic study of an unsaturated version, tetrahydroselenophene derivatives of selenophenes, has been surprisingly limited. In this way, the electrophilic cyclization appears as an alternative route to generate highly functionalized heterocycles, including selenophene derivatives. ${ }^{4}$ This methodology takes advantage, in the most of cases, by the presence of an halogen atom suitable to suffer further transformations. The purpose of this study was to report the convenient synthesis of novel tetrahydroselenophene ring systems 2 starting from 1-butylseleno-4-alkynes 1 (Figure 1).

\section{RESULTS AND DISCUSSION}
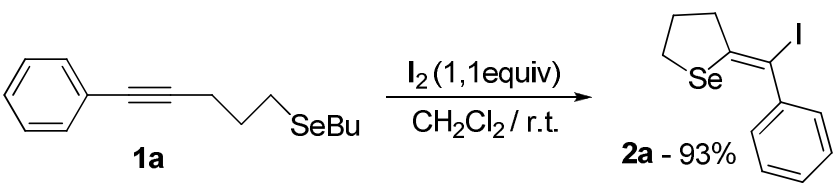

Figure 1. Optimized condition

The conditions for the cyclization were optimized by varying parameters such as solvents, reaction temperatures, amount and identity of electrophile sources. In accordance with the optimized conditions, we concluded that the optimum set to our cyclization reaction was the use of the appropriated 1-butylseleno-4-alkyne (1 equiv), electrophilic source (1.1 equiv) using $\mathrm{CH}_{2} \mathrm{Cl}_{2}(5 \mathrm{~mL})$ as the solvent and at room temperature. In order to expand the applicability of our method, we applied this condition to other substrates and the results are presented in Figure 2.<smiles>COc1cc2c(c(C(I)=C3CCCC3)c1)CCC2</smiles><smiles>Clc1ccc(C(I)=C2CCCC2)c(C=C2CCCC2)c1</smiles><smiles>Cc1ccc(C(I)=C2CCCC2)c(C)c1</smiles><smiles>FC(F)(F)c1ccc2c(c1)C(I)=C1CCC=C1C=C2</smiles><smiles>Cc1cccc2c1C1CCCC1=C(I)C2I</smiles><smiles>COC1=CC=CC2=C(OC)C(I)=C3C(=C1I)CCC23</smiles>

Figure 2. Substituted tetrahydroselenophenes prepared

\section{CONCLUSION}

In summary, we showed an efficient and regioselective iodide-promoted synthesis of tetrahydroselenophenes. A wide variety of 1butylseleno-4-alkynes bearing neutral, electrondonating and electron-withdrawing groups at the aromatic ring was compatible with the reaction conditions and yielded the corresponding tetrahydroselenophenes without any major by products and in very similar yields. Regarding the five versus six membered ring, it is important to point out that the unique product obtained during the course of this cyclization was the five membered ring.

\section{ACKNOWLEDGEMENTS}

FAPERGS (PRONEX-10/005-1), CAPES, CNPQ.

\section{REFERENCES}

${ }^{1}$ Rhoden, C. R. B.; Zeni, G. Org. Biomol. Chem, 2011, 9, 1301.

2 (a) Meotti, F. C.; Silva, D. O. Santos, A. R. S.; Zeni, G.; Rocha, J. B. T. Nogueira, C. W. Environ. Toxicol. Pharmacol. 2003, 37, 37. (b) Gonçales, C. E. P.; Araldi, D.; Panatieri, R. B.; Rocha, J. B. T.; Zeni, G.; C.W. Nogueira Life Sci. 2005, 76, 2221.

${ }^{3}$ (a) Stein, A. L.; Alves, D.; da Rocha, J. T.; Nogueira, C. W.; Zeni, G. Org. Lett. 2008, 10, 4983. (b) Alves, D.; Prigol, M.; Nogueira, C. W.; Zeni, G. Synlett 2008, 6, 914. (c) Bui, C. T.; Flynn, B. L. J. Comb. Chem. 2006, 8, 163.

${ }^{4}$ Godoi, B.; Schumacher, R. F.; Zeni, G. Chem. Rev. 2011, 111, 2937. 